\title{
Use of volume-targeted non-invasive bilevel positive airway pressure ventilation in a patient with amyotrophic lateral sclerosis ${ }^{* * * * *}$
}

\author{
Utilização de ventilação não invasiva com dois níveis \\ de pressão positiva nas vias aéreas e volume alvo \\ em paciente com esclerose lateral amiotrófica
}

\author{
Montserrat Diaz-Abad, John Edward Brown
}

\begin{abstract}
Amyotrophic lateral sclerosis (ALS) is a progressive neurodegenerative disease in which most patients die of respiratory failure. Although volume-targeted non-invasive bilevel positive airway pressure (BPAP) ventilation has been studied in patients with chronic respiratory failure of various etiologies, its use in ALS has not been reported. We present the case of a 66-year-old woman with ALS and respiratory failure treated with volumetargeted BPAP ventilation for 15 weeks. Weekly data downloads showed that disease progression was associated with increased respiratory muscle weakness, decreased spontaneous breathing, and increased use of non-invasive positive pressure ventilation, whereas tidal volume and minute ventilation remained relatively constant.
\end{abstract}

Keywords: Amyotrophic lateral sclerosis; Respiratory insufficiency; Hypoventilation; Intermittent positivepressure ventilation; Sleep.

\section{Resumo}

A esclerose lateral amiotrófica (ELA) é uma doença neurodegenerativa progressiva. A maioria dos pacientes com ELA falece por insuficiência respiratória. Embora a ventilação não invasiva com dois níveis de pressão positiva nas vias aéreas e volume alvo tenha sido estudada em pacientes com insuficiência respiratória crônica de diferentes etiologias, sua utilização em ELA não foi relatada. Apresentamos o caso de uma mulher de 66 anos com ELA e insuficiência respiratória tratada com ventilação com dois níveis de pressão positiva e volume alvo por 15 semanas. Os dados obtidos semanalmente mostraram que a progressão da doença estava associada com aumento da fraqueza muscular respiratória, redução da respiração espontânea e maior uso de ventilação não invasiva com pressão positiva, enquanto o volume corrente e a ventilação minuto permaneceram relativamente constantes.

Descritores: Esclerose amiotrófica lateral; Insuficiência respiratória; Hipoventilação; Ventilação com pressão positiva intermitente; Sono.

\section{Introduction}

Amyotrophic lateral sclerosis (ALS) is a progressive neurodegenerative disease. Most ALS patients die of respiratory failure due to progressive respiratory muscle weakness, with a median survival of less than 2 years after diagnosis. (1) Non-invasive positive pressure ventilation (NPPV) prolongs and improves the quality of life of patients with ALS. ${ }^{(2)}$ The use of volume-targeted, non-invasive bilevel positive airway pressure
(BPAP) ventilation, in spontaneous-timed (ST) mode with adjustment of inspiratory pressure to provide an estimated target tidal volume $\left(\mathrm{V}_{\mathrm{T}}\right)$, has been studied in patients with chronic respiratory failure of various etiologies. ${ }^{(3-8)}$ However, we are unaware of any reports of its use in a patient with ALS.

We report the case of a patient with ALS with rapidly progressive disease and hypercapnic

*Study carried out in the Division of Pulmonary and Critical Care Medicine, University of Maryland School of Medicine, Baltimore, MD, USA.

Correspondence to: Montserrat Diaz-Abad. Sleep Disorders Center, Division of Pulmonary and Critical Care Medicine, University of Maryland School of Medicine. 685 West Baltimore Street, MSTF 800, Baltimore, Maryland, 21201, USA.

Tel. 1410 706-4771. Fax: 1410 706-0345. E-mail: mdiaz@kunhardt.net

Financial support: None.

Submitted: 13 June 2013. Accepted, after review: 2 August 2013.

${ }^{* * A}$ versão completa em português deste artigo está disponível em www.jornaldepneumologia.com.br 
respiratory failure who was treated at home with volume-targeted BPAP ST mode ventilation. Weekly monitoring of downloaded ventilator data was accompanied by routine clinical follow-up.

\section{Case report}

A 66-year-old woman without a significant past medical history and with a body mass index of $23.4 \mathrm{~kg} / \mathrm{m}^{2}$ presented with mild bulbar symptoms followed by right foot drop. At 11 months after symptom onset, she was diagnosed with ALS. At that time, FVC was $2.22 \mathrm{~L}(79 \%$ of predicted) and MIP was $-28 \mathrm{cmH}_{2} \mathrm{O}(40 \%$ of predicted). Her ALS Functional Rating Scale (ALSFRS) score was 34 (out of 40) with a bulbar component score of 10 (out of 12), denoting mild impairment. Her Pittsburgh Sleep Quality Index (PSQ1) score was 8 (out of 21), which is consistent with poor sleep quality, whereas her Epworth Sleepiness Scale (ESS) score was 4 (out of 24), indicating no evidence of excessive daytime sleepiness.

At 4 months of follow-up, marked disease progression was evident, with worsening bulbar symptoms and fatigue, as were new conversational dyspnea, orthopnea, and nonrestorative sleep. Her pulmonary function and functional status had declined-FVC, $1.58 \mathrm{~L}$ (57\% of predicted); MIP, $-25 \mathrm{cmH}_{2} \mathrm{O}$ (36\% of predicted)-and her ALSFRS score was 28 with a bulbar component score of 8 . Sleep scores were relatively unchanged (PSQ1, 7; ESS, 4). An arterial blood gas could not be obtained after two attempts. Gastrostomy and NPPV were recommended. The patient requested further confirmatory testing prior to these interventions, and overnight in-laboratory polysomnography was scheduled for the following week.

Polysomnography revealed sleep hypoventilation. Three weeks later, volume-targeted BPAP ST ventilation titration (Average Volume-Assured Pressure Support; Philips-Respironics, Murrayville, PA, USA) was performed using a full face mask, per patient preference (Table 1). The patient could not tolerate the target $\mathrm{V}_{\mathrm{T}}(8 \mathrm{~mL} / \mathrm{kg})$. Therefore, the final settings were $V_{T}$ at $320 \mathrm{~mL}(6 \mathrm{~mL} / \mathrm{kg})$, inspiratory positive airway pressure at $8-15 \mathrm{cmH}_{2} \mathrm{O}$, expiratory positive airway pressure at $6 \mathrm{cmH}_{2} \mathrm{O}$ (increased for flow limitation), and inspiratory time at $1.5 \mathrm{~s}$, with a backup rate of 12 breaths/min. One week later, the patient returned to the clinic with continued worsening of bulbar symptoms and weakness, using a walker, and reporting dyspnea on minimal exertion. Her FVC was $1.05 \mathrm{~L}$ (38\% of predicted), with an MIP of $-19 \mathrm{cmH}_{2} \mathrm{O}(27 \%$ of predicted) and a $\mathrm{PaCO}_{2}$ of $53 \mathrm{mmHg}$. Her ALSFRS score was 26, with a bulbar component score of 6, her PSQ1 score was 17, and her ESS score was 7. Nocturnal NPPV was started with polysomnography settings and a backup rate of 14 breaths/min.

A gastrostomy tube was inserted under radiological guidance, and the patient started home hospice, with no plans to return to the clinic. Seven weeks after starting NPPV, she was contacted to adjust settings based on symptoms and downloaded data (Table 2 and Figure 1), and the patient decided to come to the clinic for a short visit to discuss her worsening dyspnea. She had mild dyspnea at rest and required a wheelchair for mobility. Nocturnal NPPV, which was used every night,

Table 1 - Sleep study data in a patient with amyotrophic lateral sclerosis.

\begin{tabular}{|c|c|c|}
\hline \multirow[t]{2}{*}{ Parameter } & \multicolumn{2}{|c|}{ Type of study ${ }^{a}$} \\
\hline & PSG & AVAPS \\
\hline Total sleep time, $\min$ & 250 & 116 \\
\hline Sleep efficiency, $\%$ & 55 & 32 \\
\hline Sleep latency, $\min$ & 58 & 113 \\
\hline Total wake time, $\min (\%)$ & $203(45)$ & $242(65)$ \\
\hline Stage $1, \min (\%)$ & $5(1)$ & $15(4)$ \\
\hline Stage $2, \min (\%)$ & $175(39)$ & 99 (27) \\
\hline Stage $3, \min (\%)$ & $71(16)$ & $15(4)$ \\
\hline REM, $\min (\%)$ & $0(0)$ & $0(0)$ \\
\hline Wake after sleep onset, min & 143 & 31 \\
\hline Arousal index, events/h & 18 & 6 \\
\hline Spontaneous arousals, $\mathrm{n}$ & 67 & 11 \\
\hline $\begin{array}{l}\text { Periodic limb movement } \\
\text { index, events/h }\end{array}$ & 1 & 0 \\
\hline $\begin{array}{l}\text { Apnea hypopnea index, } \\
\text { events/h }\end{array}$ & 0 & 0 \\
\hline Mean nocturnal $\mathrm{SpO}_{2}, \%$ & 95 & 97 \\
\hline Minimum $\mathrm{SpO}_{2}, \%$ & 93 & 94 \\
\hline Baseline $\mathrm{ETCO}_{2}, \mathrm{mmHg}$ & 46 & $47-54$ \\
\hline Maximum $\mathrm{ETCO}_{2}, \mathrm{mmHg}$ & 57 & 57 \\
\hline $\mathrm{ETCO}_{2}>50, \min$ & 227 & 121 \\
\hline Baseline RR, breaths/min & - & 24 \\
\hline Final $\mathrm{ETCO}_{2}, \mathrm{mmHg}$ & - & $35-45$ \\
\hline Final RR, breaths/min & - & $12-14$ \\
\hline
\end{tabular}

PSG: polysomnography; AVAPS: average volume-assured pressure support; REM: rapid-eye-movement sleep; and $\mathrm{ETCO}_{2}$ : end-tidal $\mathrm{CO}_{2}$. ${ }^{a}$ The patient performed both studies recumbent at approximately $45^{\circ}$. 
Table 2 - Weekly ventilator data downloads for an amyotrophic lateral sclerosis patient on bilevel positive airway pressure ventilation.

\begin{tabular}{|c|c|c|c|c|c|c|c|c|c|c|c|c|c|c|c|}
\hline \multirow[t]{2}{*}{ Variable } & \multicolumn{15}{|c|}{ Week } \\
\hline & 1 & 2 & 3 & 4 & 5 & 6 & 7 & 8 & 9 & $10^{\mathrm{a}}$ & 11 & 12 & 13 & 14 & 15 \\
\hline $\mathrm{V}_{\mathrm{E}}, \mathrm{L} / \mathrm{min}$ & 4.3 & 4.5 & 4.4 & 4.4 & 4.3 & 4.5 & 5.8 & 5.4 & 5.5 & 6.5 & 7.1 & 6.4 & 5.9 & 6.3 & 6.5 \\
\hline $\mathrm{V}_{\mathrm{T}}, \mathrm{mL}$ & 271 & 267 & 266 & 259 & 265 & 259 & 295 & 273 & 252 & 310 & 354 & 346 & 336 & 336 & 338 \\
\hline Trigger, \% & 77 & 82 & 77 & 78 & 76 & 80 & 90 & 87 & 78 & 63 & 55 & 47 & 43 & 46 & 50 \\
\hline Daily use, $\mathrm{h}$ & 5.0 & 3.9 & 6.1 & 5.7 & 5.4 & 5.3 & 5.6 & 6.0 & 10.1 & 12.9 & 11.8 & 12.4 & 10.3 & 13.7 & 17.6 \\
\hline Use $\geq 4$ h/day, $\%$ & 71 & 43 & 100 & 100 & 86 & 86 & 86 & 100 & 100 & 86 & 100 & 100 & 43 & 100 & 100 \\
\hline $\mathrm{RR}$, breaths/min & 19 & 19 & 20 & 19 & 20 & 20 & 22 & 23 & 25 & 24 & 22 & 20 & 20 & 21 & 22 \\
\hline $\mathrm{AHl}$, events/h & 15.2 & 19.4 & 25.8 & 21.6 & 19.1 & 23.2 & 5.2 & 13.4 & 22.3 & 26.8 & 7.7 & 15.1 & 11.4 & 5.5 & 12.7 \\
\hline Leak, L/min & 40 & 40 & 41 & 38 & 42 & 38 & 36 & 39 & 41 & 38 & 38 & 36 & 36 & 35 & 36 \\
\hline IPAP, $\mathrm{cmH}_{2} \mathrm{O}$ & 11.9 & 11.9 & 12.9 & 12.8 & 12.5 & 12.6 & 10.9 & 11.8 & 13.5 & 15.0 & 13.8 & 13.5 & 14.2 & 14.0 & 14.5 \\
\hline
\end{tabular}

$\mathrm{V}_{\mathrm{E}}$ : minute ventilation; $\mathrm{V}_{\mathrm{T}}$ : tidal volume; Trigger: patient-triggered (spontaneous) breaths; Daily use: device use per 24-h period; Use $\geq 4 \mathrm{~h}$ /day: days on which the device was used for $\geq 4 \mathrm{~h} /$ day; AHl: apnea-hypopnea index; Leak: total

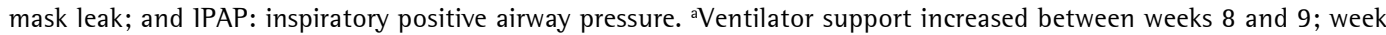
10 reflects this increase for the first complete week.
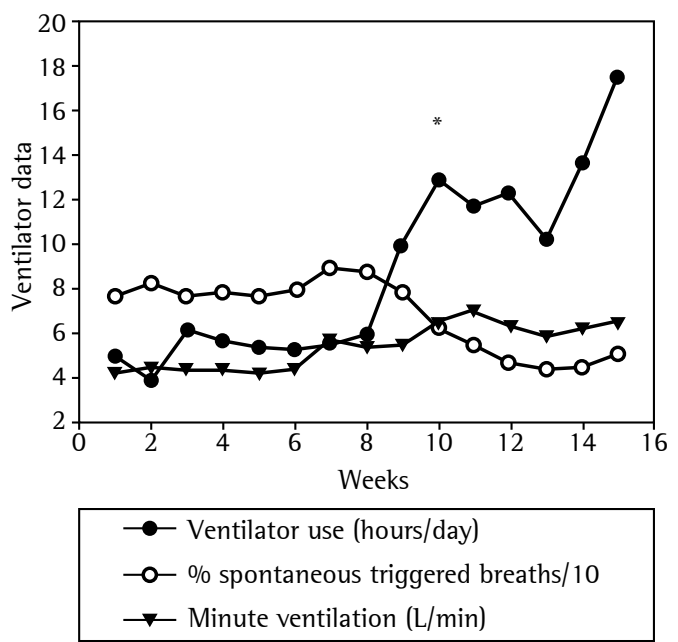

Figure 1 - Ventilator data for a 15-week period in an amyotrophic lateral sclerosis patient on bilevel positive airway pressure ventilation. Note the increased duration of daily use of ventilation with decreased ability to trigger breaths spontaneously (i.e., increased reliance on timed ventilator-delivered breaths) over time. As can be seen, minute ventilation remained relatively constant. *Ventilator support increased between weeks 8 and 9; week 10 reflects this increase for the first complete week.

helped ease breathing, allowing her to sleep better and longer. She had recently developed a mask leak due to weight loss. At that time, FVC was $1.01 \mathrm{~L}$ (36\% of predicted), MIP was -15 $\mathrm{CmH}_{2} \mathrm{O}$ (21\% of predicted) and $\mathrm{PaCO}_{2}$ was 55 $\mathrm{mmHg}$. Settings were adjusted to $\mathrm{V}_{\mathrm{T}}$ at $370 \mathrm{~mL}$ $(7 \mathrm{~mL} / \mathrm{kg})$, inspiratory positive airway pressure at 10-17 $\mathrm{cmH}_{2} \mathrm{O}$, and inspiratory time at $1.2 \mathrm{~s}$, with a backup rate of 18 breaths/min. Intermittent daytime NPPV use and a new mask fitting were recommended. Contact with the patient (via telephone and e-mail) was maintained, and the changes were well tolerated. At 6 weeks after her last visit, she was again contacted to adjust settings but declined to make further changes. Shortly thereafter, she died of progressive respiratory failure.

\section{Discussion}

We have presented the case of a patient with ALS treated for chronic respiratory failure with volume-targeted BPAP ST mode ventilation for 15 weeks, in whom the use of weekly monitoring of ventilator data in addition to routine care provided useful information for management of respiratory failure. Disease progression was associated with worsening respiratory muscle weakness, a decrease in spontaneous breathing, and increased use of NPPV, although $V_{T}$ and minute ventilation $\left(\mathrm{V}_{\mathrm{E}}\right)$ remained relatively constant. To our knowledge, the use of this mode of NPPV has not been reported in ALS.

Among patients with ALS, the progression of the disease is relatively rapid but varies. ${ }^{(9)}$ Therefore, serial NPPV pressure adjustments may be required in order to compensate for declining respiratory muscle strength and increasing hypercapnia. ${ }^{(10)}$ An NPPV mode with an inspiratory pressure range to maintain a target $\mathrm{V}_{\mathrm{T}}$, rather than a fixed pressure, might reduce the frequency of required adjustments over time 
in some patients. This feature might also be of benefit in the short term, such as during sleep, when patients with diaphragmatic weakness are vulnerable to worsening hypoventilation, especially during rapid-eye-movement sleep. Ambogrio et al. showed that, in comparison with traditional BPAP ST mode ventilation, volumetargeted BPAP ST mode ventilation was better able to maintain $\mathrm{V}_{\mathrm{E}}$ (by maintaining $\mathrm{V}_{\mathrm{T}}$ ) during sleep in patients with obesity hypoventilation syndrome. ${ }^{(4)}$

The built-in software of NPPV devices is proprietary, and, in the absence of independent validation, the data provided on many parameters should be considered as indicators of trends without any guarantee as to linearity of the estimations provided. ${ }^{(11)}$ Despite this limitation, the available data can provide valuable information for patient management. Studies involving remote monitoring of NPPV compliance data in patients with ALS using traditional BPAP ventilation have shown that such monitoring reduces health care utilization and hospital admissions, potentially reducing overall health care costs, in comparison with routine care. ${ }^{(12)}$ This monitoring modality could be particularly useful in patients with rapidly progressive or advanced ALS, who, like our patient, might be homebound. The ability to request and verify changes to the settings remotely (without a home visit) is an additional advantage.

Volume-targeted BPAP ST mode ventilation is a relatively new alternative to traditional NPPV for patients with respiratory failure, and we have reported its use for the first time in a patient with ALS. Additional studies are needed in order to compare the various NPPV modes, in terms of their effect on survival, quality of life, sleep quality, adherence, adequacy of ventilation, and health care utilization, in ALS patients.

\section{References}

1. Louwerse ES, Visser CE, Bossuyt PM, Weverling GJ. Amyotrophic lateral sclerosis: mortality risk during the course of the disease and prognostic factors. The Netherlands ALS Consortium. J Neurol Sci. 1997;152 Suppl 1:S10-7. http://dx.doi.org/10.1016/ S0022-510X(97)00238-4
2. Bourke SC, Tomlinson M, Williams TL, Bullock RE, Shaw PJ, Gibson GJ. Effects of non-invasive ventilation on survival and quality of life in patients with amyotrophic lateral sclerosis: a randomised controlled trial. Lancet Neurol. 2006;5(2):140-7. http://dx.doi.org/10.1016/ S1474-4422(05)70326-4

3. Storre JH, Seuthe B, Fiechter R, Milioglou S, Dreher M, Sorichter $\mathrm{S}$, et al. Average volume-assured pressure support in obesity hypoventilation: A randomized crossover trial. Chest. 2006;130(3):815-21. http://dx.doi.org/10.1378/ chest.130.3.815

4. Ambrogio C, Lowman X, Kuo M, Malo J, Prasad AR, Parthasarathy $\mathrm{S}$. Sleep and non-invasive ventilation in patients with chronic respiratory insufficiency. Intensive Care Med. 2009;35(2):306-13. http://dx.doi.org/10.1007/ s00134-008-1276-4

5. Janssens JP, Metzger M, Sforza E. Impact of volume targeting on efficacy of bi-level non-invasive ventilation and sleep in obesity-hypoventilation. Respir Med. 2009;103(2):165-72. http://dx.doi.org/10.1016/j. rmed.2008.03.013

6. Crisafulli E, Manni G, Kidonias M, Trianni L, Clini EM. Subjective sleep quality during average volume assured pressure support (AVAPS) ventilation in patients with hypercapnic COPD: a physiological pilot study. Lung. 2009;187(5):299-305. http://dx.doi.org/10.1007/ s00408-009-9167-1

7. Vagiakis E, Koutsourelakis 1, Perraki E, Roussos C, Mastora Z, Zakynthinos S, et al. Average volume-assured pressure support in a 16-year-old girl with congenital central hypoventilation syndrome. J Clin Sleep Med. 2010;6(6):609-12.

8. Murphy PB, Davidson C, Hind MD, Simonds A, Williams AJ, Hopkinson NS, et al. Volume targeted versus pressure support non-invasive ventilation in patients with super obesity and chronic respiratory failure: a randomised controlled trial. Thorax. 2012;67(8):727-34. http:// dx.doi.org/10.1136/thoraxjnl-2011-201081

9. Radunovic A, Mitsumoto H, Leigh PN. Clinical care of patients with amyotrophic lateral sclerosis. Lancet Neurol. 2007;6(10):913-25. http://dx.doi.org/10.1016/ S1474-4422(07)70244-2

10. Gruis KL, Brown DL, Lisabeth LD, Zebarah VA, Chervin RD, Feldman EL. Longitudinal assessment of noninvasive positive pressure ventilation adjustments in ALS patients. J Neurol Sci. 2006;247(1):59-63. http://dx.doi.org/10.1016/j. jns.2006.03.007

11. Janssens JP, Borel JC, Pépin JL; SomnoNIV Group. Nocturnal monitoring of home non-invasive ventilation: the contribution of simple tools such as pulse oximetry, capnography, built-in ventilator software and autonomic markers of sleep fragmentation. Thorax. 2011;66(5):43845. http://dx.doi.org/10.1136/thx.2010.139782

12. Pinto A, Almeida JP, Pinto S, Pereira J, Oliveira AG, de Carvalho M. Home telemonitoring of non-invasive ventilation decreases healthcare utilisation in a prospective controlled trial of patients with amyotrophic lateral sclerosis. J Neurol Neurosurg Psychiatry. 2010;81(11):123842. http://dx.doi.org/10.1136/jnnp.2010.206680 


\section{About the authors}

\section{Montserrat Diaz-Abad}

Physician. Sleep Disorders Center, University of Maryland; and Assistant Professor of Medicine. University of Maryland School of Medicine, Baltimore, MD, USA.

\section{John Edward Brown}

Physician. Sleep Disorders Center, University of Maryland; and Assistant Professor of Medicine. University of Maryland School of Medicine, Baltimore, MD, USA. 